\title{
PERSPECTIVIZATION AND MODES OF QUOTING IN HUNGARIAN*
}

\author{
SZILÁRD TÁTRAI - NÓRA CSONTOS \\ Department of Hungarian Department of Hungarian \\ Linguistics Linguistics \\ Eötvös Loránd University Károli Gáspár University \\ Múzeum krt. 4/A Reviczky u. 4/C \\ H-1088 Budapest H-1088 Budapest \\ Hungary \\ Hungary \\ tatraisz@yahoo.com \\ csontosnora@gmail.com
}

\begin{abstract}
This paper examines modes of quoting with special regard to the organization of perspective. Due to the pragmatic interest of the study, our focus is on the functioning of two context-dependent vantage points, the subject of consciousness and the referential centre. Our key question about the former is to whom speaking as a sign of active consciousness is attributed and how this is linguistically marked. As regards the latter, the central issue is from where and how the spatio-temporal and interpersonal relations of the quoted discourse are represented.

Further problems to be discussed include the questions of how and to what extent quoting is associated with pragmatic or metapragmatic awareness, and how various quoting modes may differ along this dimension.

Although the paper is mostly concerned with a 'universal pragmatic' characterization of the functioning of perspective in quotations, it also highlights some language-particular features of Hungarian quoting strategies and touches on their evolution in the history of the language.
\end{abstract}

Keywords: pragmatic perspective, perspectivity in language, embedded utterances, subject of consciousness, referential centre

* Nóra Csontos was supported in her work by the Deák Ferenc Scholarship granted by the Hungarian Ministry of Education. Szilárd Tátrai's work was sponsored by the Bolyai János Scholarship of the Hungarian Academy of Sciences. The authors thank Piroska Kocsány and Jef Verschueren for providing useful comments on the manuscript. 


\section{Introduction. Background in pragmatic theory}

In any given discourse, the participants have at their disposal the possibility of evoking other discourses by embedding them into their own utterances. In the present study, we address (and re-formulate) the questions concerning the most typical modes of quoting from a functional cognitive pragmatic perspective. By doing so, we hope to provide an interpretive framework which may contribute to a better understanding of the functioning of quotations. In pursuit of this task, one of our key concerns will be to offer illustrations of some of the language-particular features of Hungarian quoting strategies.

In line with the assumptions of functional cognitive linguistics, we adopt an interpretation of pragmatics whereby language use is regarded as meaningful functioning within a discourse context rather than something to be defined against, and hence more or less separated off, the workings of an autonomous syntactic module (Verschueren 1999; cf. also Mey 2001; Tomasello 1999; Sinha 1999). This 'pragmatic perspective' suggests that quoting may be described in the matrix of such notions (central to the functioning of language in general) as adaptation, contextualization, and perspectivity.

- Language use can be interpreted as adaptation (adaptive human activity) because it is geared towards the satisfaction of a wide range of human communicative needs. Motivated by these needs, human beings tend to employ forms of expression which best suit the purpose of communication, i.e., the needs and expectations of the interlocutors, and their knowledge states in the current discourse space (Verschueren 1999, 55-70). In this context, the most relevant question is to what end and how speakers evoke other discourses or parts thereof.

- Language use can also be regarded as the dynamic construal of meaning by successive utterances in a given context. The context, as we see it, has no existence independently of the utterance; rather, it is generated as the utterance unfolds by the activation of various kinds of information pertaining to the current situation, the purpose and theme of the discourse, etc. This process of contextualization is the key to attaining a suitably relevant interpretation of the utterance, i.e., one that is in accord with the circumstances and needs of communication (cf. Verschueren 1999, 75-114; Tátrai 2004). With regard to quoting, the significance of contextualization comes from the 
fact that quoted discourses are extracted from their original contexts and embedded into new ones, which may radically alter the conditions for their interpretation. At the same time, embedded utterances also retain (through intertextuality) certain features of their original contexts and conditions for interpretation.

- Finally, language use can also be viewed as a social-cognitive activity, which has the sine qua non feature of providing the means for creating jointly accessible (intersubjective) world representations (cf. Tomasello 1999; Sinha 1999; 2001). In addition to being intersubjective, these world representations also show high degrees of perspectivity. This is because in and through their utterances, speakers intend to modify, from their own context-dependent vantage point(s), the hearer's mental orientation in order that they jointly attend to a referential situation and interpret it in a particular way (cf. Verschueren 1999, 113-46; Sinha 2001; Langacker 2001; Evans 2007). As far as quotation is concerned, the crucial task is to decide which vantage point(s) a given embedded discourse (or discourse part) is represented from, i.e., how it is organized in terms of perspective.

The focus of the present paper is on the pragmatic study of perspective; adaptation and contextualization are only discussed in relation to this focal point. Throughout the analysis, we rely heavily on the relevant concepts and results of functional cognitive linguistics (e.g., Langacker 1987; Sanders-Spooren 1997; Tomasello 1999). Since our study is of a primarily pragmatic interest, the emphasis will be on those aspects of the phenomena that bear the most direct relation to contextual factors. Our guiding assumption is that quoting inherently involves perspectivization, with the subject of consciousness positioned in the speaker of the embedded rather than the matrix utterance. By virtue of being the subject of consciousness, the embedded speaker is responsible for the information being communicated, and it is to her that the act of speaking as a sign of active consciousness is attributed (see Sanders-Spooren 1997). This is highly relevant for the study of quoting, as the displacement of the subject of consciousness can be made explicit to varying degrees, with strong repercussions for the construal of meaning. Comparable in significance to the issue of where the active consciousness is located is the question of what vantage point(s) the spatio-temporal and interpersonal relations of the embedded discourse are represented from. Following the terminology of Sanders and Spooren (1997), we call this vantage point the referential centre. 
In section $\mathbf{2}$, we provide some further clarification of the basic notions adopted in the paper. In section $\mathbf{3}$, we present evidence from Hungarian to suggest that the functioning of the referential centre may be the key to distinguishing between various modes of quoting. Finally, section $\mathbf{4}$ is devoted to the study of how and to what extent each mode of quoting may correlate with pragmatic or metapragmatic reflection, with possible implications for the contextual interpretation of embedded utterances.

Throughout the paper, we are concerned not only with the universal pragmatic aspects of quoting but also with the language-specific features of Hungarian, including the historical development of its quoting strategies. ${ }^{1}$ In a functional cognitive framework, no sharp dichotomy is assumed between synchrony and diachrony; rather, historical and descriptive approaches are seen as jointly applicable, mutually presupposing each other (cf. Blank-Koch 1999). Inevitably, adopting a historical perspective entails a certain bias for the written register. Up until the 20th century, the data come exclusively from written documents, and only cautious comments can be made on quoting in the spoken form of language. We hope that the selected samples will go some way to illustrating the phenomena under investigation; we are aware, however, that the results may need empirical confirmation by a more full-scale study applied to a larger corpus. Although some of our findings may be preliminary, we hope that future studies will benefit from the concepts and results presented here.

\section{Quoting as perspectivization}

Quoting can be regarded as a prototypical feature of human language for establishing points of contact between discourses in an intertextual space (cf. Beaugrande-Dressler 1981, 235-67; Givón 1990, 530-2; Genette 1997). Significantly, in contrast to adjacency pairs in conversation, or exchanges in written correspondence with a question-answer structure, there is no reciprocity of relations here: the matrix discourse presupposes the existence of the embedded one without the reverse being true. ${ }^{2}$

${ }^{1}$ For a more detailed study of the evolution of Hungarian modes of quoting, see Csontos-Tátrai (2008).

${ }^{2}$ Quoting may also receive a broader interpretation, whereby it includes the evoking of thoughts (or streams-of-consciousness) as well as explicit communication (cf. Cohn 1978; Kocsány 1996). This issue is, however, beyond the scope of this paper. 
From this it also follows that embedded discourses/discourse parts may come in various shapes and sizes, from full texts to even single words. At one prototypical level in the continuum, the embedded discourse is represented by a single clause. The other extreme takes the form of a multi-propositional discourse (Givón 1998, 43) expressing a highly complex world representation comprising a series of events. As we shall see later on, the extent of an embedded utterance may also correlate with the mode of quoting a speaker adopts.

Modes of quoting are typically distinguished by examining the degree to which the actual speaker relies on the form of the embedded utterance. The common practice (to which we also subscribe) is to posit three main types on this basis: direct, indirect, and free indirect speech. By direct speech we mean the grammatically well-established mode of quoting whereby the actual speaker provides a literal rendition of the embedded discourse. Indirect speech is similarly well established: it is a grammaticized construction adopted when the actual speaker has no intention to evoke the embedded discourse in its original form, focusing instead on its propositional content. Free indirect speech, for its part, is given a slightly broader interpretion here than generally assumed. We regard it as an umbrella term for less consistent modes of quoting with a mix of properties shared by either of the more well-established constructions. At this level of generalization, then, free indirect speech receives a negative definition, accounting for a much more open and heterogeneous category than either direct or indirect speech.

In the processing of a discourse, it is of paramount importance from which vantage point(s) the actual speaker provides an intersubjective representation of her experience (cf. Langacker 1987; 1991; Sanders-Spooren 1997; Tomasello 1999). Usually, world representations are the cumulative results of the application of multiple vantage points, each contributing to the organization of perspective.

Sanders and Spooren (1997) distinguish three main types of vantage point: the neutral vantage point, the referential centre, and the subject of consciousness (cf. also Tolcsvai Nagy 2001, 125-7; Tátrai 2008). The neutral vantage point is linked primarily to the processing of clause-level stretches of discourse: it is located in the entity from whose perspective the basic event (scene, process) is represented. This is neutral in the sense that the entity in question is not necessarily grounded in the immediate context of the speech event. Hence, it is for predominantly semantic approaches to the construal of meaning that the neutral vantage point 
may be especially relevant. The other two vantage points, by contrast, are inextricably linked to the activation of contextual information. As a result, they invite a predominantly pragmatic approach addressing the more dynamic and context-bound aspects of meaning construal.

- The referential centre (also known as the deictic centre in the literature) marks the point of orientation from which the spatial, temporal, and interpersonal relations portrayed in the utterance are represented. By default, the referential centre resides with the actual speaker and her position in space and time. However, speakers also have the option of displacing the referential centre (in part or in full) onto another entity (usually another person) or to another point in space or time.

- The subject of consciousness is the entity to whom the signs of active consciousness (perception, volition, cognition, or speech) are attributed. By default, the subject of consciousness is again the actual speaker herself. However, just as we have seen with the referential centre, this vantage point may also be displaced onto others.

In effect, then, the referential centre and the subject of consciousness may be seen as context-dependent vantage points inherently bound to the discourse participant functioning as the actual speaker. Their domains of application span complete utterances, since their displacement can only be successfully inferred in view of the position of the speaker. On a general note, then, an utterance may be suitably defined as a usage event whereby the speaker as a discourse participant adopts her own set of context-dependent vantage points in an attempt to modify the mental orientation (attentive/interpretive procedures) of another discourse participant in the generation of a discourse universe (cf. Verschueren 1999, 113-46; Langacker 2001; Sinha 2001).

The functioning of these vantage points is of course a crucial factor in the conceptual (and concomitantly, the linguistic) representation of embedded discourses and discourse parts. Each time the actual speaker embeds someone else's discourse or discourse part into her utterance, she makes the embedded speaker responsible for the message being communicated. As far as the quotation extends, the embedded speaker is held up as the subject of consciousness, to whom the act of speaking as a sign of active consciousness is attributed. More generally, the phenomenon highlights that language as a social-cognitive activity is grounded in intersubjective rather than objective reality (cf. the notion of subjunc- 
tivizing ${ }^{3}$ reality in Bruner (1986, 11-29), and the notion of referential realism in Sinha (1999, 229-34)). Human beings perceive each other as mental agents like themselves; hence, they can adopt each other's perspective, and conceptualize the mental worlds of others (cf. Tomasello 1999).

The displacement of the subject of consciousness (as a typical form of perspectivization, cf. Sanders-Spooren 1997, 86-95) is an inherent aspect of quotation. This suggests that each mode of quoting may be characterized in terms of how and to what extent such displacements are grammatically marked.

In cases of direct speech, there is usually a main clause introducing, interrupting or closing down the embedded discourse, which makes for a linguistically explicit marking of perspectivization. From the earliest written records of Hungarian to the mid-19th century, the quoting clause is rarely omitted (cf. Csontos-Tátrai 2008, 82-7). From the mid-19th century, however, quoting clauses are increasingly dropped (especially in embedded conversations) as a result of the spread of orthographic conventions taking their place. ${ }^{4}$ By formally separating embedded utterances from their linguistic contexts, these conventions (e.g., the use of italics, quotation marks, or dashes) are capable of serving the same function as a quoting clause, i.e., making explicit the displacement of the subject of consciousness along with the referential centre.

(1) Úgy már kellemetes vagy, azt mondja reá az Asszony, és hizelkedhetem azzal magamnak, hogy különös szeretöm vagyon: [.. .] De édes fiam! te még ifjú vagy; vagyon olyan szempillantás, midőn az ember nem bír indulataival, és félek ne hogy veszedelemre vessem hivségedet, midőn kivánságaidra eresztelek — Légy csendességben, Asszonyom! (Báróczy 1814, 19).

'You are pleasurable now, the lady responds, and I can flatter myself for having such an extraordinary lover: [...] But my dear son! you are so young; there are

3 'I take my meaning of 'subjunctive' from the second one offered by the OED: 'Designating a mood (L. modus subjunctivus) the forms of which are employed to denote an action or state as conceived (and not as a fact) and therefore used to express a wish, command, exhortation or a contingent, hypothetical, or prospective event.' To be in the subjunctive mode is, then, to be trafficking in human possibilities rather than in settled certainties. An 'achieved' or 'uptaken' narrative speech act, then, produces a subjunctive world. When I use the term of subjunctivize, I shall mean it in this sense." (Bruner 1986, 26)

${ }^{4}$ Up until the mid-19th century, orthographic conventions only served as auxiliary devices for making displacements more conspicuous; they did not trigger the loss of the quoting clause (cf. Csontos 2009). 
moments when emotions possess us, and I fear lest I abuse your affection when I leave you to your desires-Not a word, Madam!'

In (1), the first turn in the conversation is interrupted by a quoting clause (azt mondja reá az asszony 'the lady responds'). In subsequent turns, however, the dash alone serves to signal that the actual speaker shifts the subject of consciousness and the referential centre from one embedded discourse participant to another.

In a way similar to direct speech, indirect speech is characterized by linguistically explicit markers of perspectivization. Generally, the main clause serves the purpose of identifying the subject of consciousness. However, whereas in direct speech, the embedded speaker is made responsible for the form as well as the propositional content of the quoted utterance, in indirect speech she only accounts for the latter.

(2) Mit tselekedtek a' régi Rómaiak amaz ékeflen fzólló Ciceroval? Maga panafzollya, hogy a' Kormányról a' hajónak undok fenekére le-tafzították ([Vég-Veresmarti] $1797,3)$

'What did the old Romans do to that eloquent Cicero? He himself complains that from the helm he was pushed to the disgraceful bottom of the ship.'

In the quoting clause of (2), the active consciousness is evoked by the verb panaszolja 'complains.' ${ }^{5}$ Interestingly, the verb forms portraying the active consciousness tend to be more varied in indirect than in direct speech. The most natural explanation seems to be that in indirect speech, the embedded utterance is supposed to report only the propositional content of the utterance; hence, any speaker attitude attached to it is left for the quoting passage to describe (cf. Kocsány 1996, 337).

Traditional approaches employ the term free indirect speech for cases lacking a quoting clause (cf. Murvai 1980; Kocsány 1996). As already men-

${ }^{5}$ Indirect speech may be regarded as a grammaticized construction because of its evolution. Running in parallel to the development of subordinate clauses, the evolution of indirect speech saw two, originally independent clauses entering into a close grammatical relationship, by one of the two subordinated to a verb of speech, sense, or cognition. For illustration, consider: Látja/Mondja 'He sees/He says' + Hogy esik/hogyan esik 'How it rains' > Látja/Mondja, hogy esik 'He sees/ He says that it rains'. (The Hungarian subordinating conjunction hogy 'that' is derived from the wh-word hogyan 'how'.) The grammatical dependence of the embedded clause is marked by the conjunctions hogy or mert (meaning only 'because' in present-day Hungarian but formerly also associated with a similar function as hogy). For a more detailed discussion, see Haader (2003). 
tioned above, our own interpretation is different by relying on functional rather than formal criteria. In particular, we adopt the notion as an umbrella term for quoting strategies deviating in certain respects from both direct and indirect speech. Naturally, this may also include cases where the subject of consciousness is underspecified, creating ambiguity. In such situations, it becomes uncertain who is responsible for the message being communicated, or rather, what share each discourse participant (the actual speaker included) has in accounting for the information.

(3) Zófia asszony azt véleményezte, hogy egészen cseléd módjára kell szoktatni; szokjék a konyhához, a mosáshoz, a vasaláshoz: annak veszi hasznát. Úgysem veheti el más olyan kevés pénz mellett, mint valami „schreiber”, egy hajóbiztos; arra nézve pedig sokkal jobb, ha a felesége szolgálónak volt szoktatva, mint kisasszonynak. (Jókai 1873/1981, 133)

'Lady Sophie was of the opinion that they should treat her as a maid in earnest; let her apply herself to kitchenwork, washing, ironing: that's what her own best interest dictates. Nobody would marry her anyway, what with so little endowment, except for a "scribbler", or shipmaster; and such a one would much prefer a maidservant for a wife to a mademoiselle.'

In the first sentence of (3), perspectivization is explicitly and unambiguously marked (Zófia asszony azt véleményezte 'Lady Sophie was of the opinion that...'). In the second sentence, however, it remains implicit, although apparently we are still being informed about Lady Sophie's opinion. ${ }^{6}$ In the absence of the explicit marking of perspectivization, it becomes somewhat uncertain who and to what extent accounts for the propositional content of the utterance, who and to what extent may be linked to the act of speaking as a sign of active consciousness.

\section{The functioning of the referential centre in Hungarian quoting modes}

As we have suggested above, the pragmatic study of typical modes of quoting requires the analysis of both the subject of consciousness and the referential centre. Of these two, it is the latter which supplies the vantage point from which the spatio-temporal relations (physical world) and interpersonal relations (social world) of the quoted utterance are represented in a particular way. Hence, the study of perspectivization

${ }^{6}$ Note that stylistic features such as word choice (cf. the use of scribbler in the example) may contribute to the identification of the subject of consciousness. 
needs to go further than the issues of "the landscape of consciousness" (see Bruner 1986, 14). Specifically, it also needs to address the problems pertaining to the referential interpretation and grounding of quotations. ${ }^{7}$

Generally speaking, the actual speaker has three main options to choose from when embedding someone else's discourse into her utterance. First, she may shift the referential centre completely onto the embedded speaker (direct speech). Second, she may retain control of the referential centre, so that she and her position in space and time continue to serve as the centre of orientation (indirect speech). Third, she may shift the referential centre partially, in which case the actual speaker and the embedded one make a joint contribution to the organization of perspective (as in some forms of free indirect speech). ${ }^{8}$

In this section, we provide an overview of each mode of quotation by first mentioning their general features in terms of the functioning of the referential centre, then moving on to the (diachronic as well as synchronic) analysis of certain Hungarian-specific phenomena. No attempt is made here to provide a full-scale presentation of the evolution of quoting modes; rather, we will focus on historical facts that appear to be the most directly relevant for a predominantly synchronic study.

3.1. The use of direct speech reflects the speaker's intention to evoke the embedded speaker's utterance literally, by preserving its original form and structure. This intention can only be realized by the displacement of the referential centre onto the embedded speaker for the entire length of the quotation. Hence, in direct speech, the embedded speaker functions as the centre of referential orientation for assessing spatio-temporal and interpersonal relations. ${ }^{9}$

${ }^{7}$ Under the interpretation of the referential (or deictic) centre as an all-embracing notion including spatial, temporal, and interpersonal relations, its functioning may shed light on the close relationship between the physiological and the social factors determining linguistic cognition; in other words, on the connection between embodied grounding and discursive grounding (cf. Sinha 1999), united in Zlatev's (1997) notion of situated grounding.

8 On the egocentric orientation of deictic expressions, see Bühler (1934), Fillmore (1975), Lyons (1977/1989), and Levinson (1983/1992; 2004).

${ }^{9}$ Alternatively, one might argue that there are two deictic centres in direct speech (i.e., the actual speaker in the quoting part, and the embedded speaker in the quoted part), which can be merged into one in indirect speech. 
(4) (a) — Most eljössz innen! — kiáltottam rá. (Mészöly 1979, 9)

'Now you come away from here! - I shouted at him.'

(b) — A víz beomlasztotta a szurdikot... kicsit sokáig tartott a kubikolás mondta Teleszkai. (Mészöly 1979, 19)

'The water made the gorge collapse... it took us quite a while to do the navvies' job-Teleszkai said.'

In (4a) the speaker, i.e., the fictitious narrator of the short story, is embedding his own previous utterance into his actual utterance by quoting it in direct speech. Hence, the second person singular verb form eljössz 'you come' is directed at the addressee of the embedded rather than the actual speaker. Concomitantly, it is the embedded speaker who serves as the centre of interpersonal orientation, so that all other discourse participants are accessed and interpreted from his perspective. Furthermore, he also functions as the centre of spatio-temporal orientation, as the spatial deixis inherent in innen 'from here' and eljössz 'you come', as well as the temporal deixis of most 'now', suggest, although in this particular case the positions of the speaker and the addressee are nearly identical. Note that in the absence of deictic expressions, the displacement of the referential centre has to be marked by other devices. In cases like (4b), orthographical conventions (here, the use of dashes) assist the reader in recognizing the use of direct speech and the complete displacement of the referential centre that this entails.

As regards the evolution of direct speech in Hungarian, it may be worth mentioning that early medieval texts used to employ a much wider range of tenses than present-day Hungarian, under the influence of Latin. There were four past tenses: the narrative past (marked by the $-a /-e$ suffix), the past tense with the $-t$ suffix, and two composite tenses $(\varnothing+$ vala, $-t+$ vala), each of which may have been reserved for specific functions as far as the functioning of the referential centre is concerned. In particular, it seems that the narrative past is typically adopted in the quoting clauses represented from the actual speaker's perspective, whereas the other three past tenses reflect the vantage point of an embedded speaker in the direct quote. Hence, these latter establish the relative chronology of the events described in the embedded utterance vis-à-vis the embedded speaker's vantage point, bearing no direct relation to the actual speaker's perspective (cf. Abaffy 1991, 118-19; Sárosi 2003, 362-4). 
(5) Felele neky ihesus Teen tọleed mondodee ezth awagh egebek mondottak nekọd een felolem ${ }^{10}$ (WinklK. [1506] 182)

'Jesus replied to him, do you say this by yourself (by your own conviction), or have others told it to you about me?'

In the quoting clause of (5), the verb form felele 'replied' is in the narrative past, and refers to an event that happened prior to the present marked by the actual speaker's position. By contrast, in the passage quoted in direct speech, it is the embedded speaker who functions as the centre of temporal orientation, as the present-tense verb form mondod 'you say' suggests. Hence, it is also in relation to this centre of orientation that the time reference of the verb form with the - $t$ suffix (mondották 'they told') receives an interpretion. As a word of caution, it should be emphasized that this system of four past tenses is documented primarily in the codices, i.e., a body of texts that are known to show a rather strong Latin influence. In the non-prototypical corpus segments reflecting the oral use of language (e.g., court minutes, private letters), only two past tenses $(-t+$ vala, $-t)$ are typically used (cf. Sárosi 2003, 367-8).

As is to be expected in cases of direct speech, the passage in (5) also exemplifies the displacement of the centre of interpersonal orientation. The first person singular form énfelólem 'about me' strongly highlights the position of this centre by the emphatic use of the personal pronoun én 'I' before felölem 'about me' whose -em suffix (historically derived from the personal pronoun) already marks first person singular. This kind of overspecification is widely attested in Old Hungarian texts. Further expressions whose reference can only be interpreted by assuming the embedded speaker's centre of orientation include the emphatic second person pronoun tetőled 'by yourself, (lit.) from you', again showing overspecification ( $t e$ ' $y o u$ ', $-e d$ ' $2 \mathrm{sg}$ '), and the third person form egyebek 'others'. In addition, ezt 'this-acc' as a marker of discourse deixis also suggests a complete displacement of the referential centre, reflecting as it does the vantage point of the embedded speaker.

Direct speech was also available at the time (as it always has been) as a means for embedding multiple utterances linked to multiple speakers (e.g., turns of a conversation). In such cases, the referential centre is on the move from one turn to another.

${ }^{10}$ Our transcriptions of manuscript examples follow the conventions of the editions listed in the references. In the explanations, however, we provide modern transcriptions to aid understanding. 
(6) Monda az vitez. hagyad meg vram bÿro hog mynden ember vezteg halgaflon. kÿ meg leuen monda az vitez. Vram byro jme ez az ellev jgaz mondas. [...] Az byro ezeket halvan. monda az kevrnÿvl alloknak. jgaze ez amÿt mond ez vitez. mondanak evk. ha gonozvl tevev nem volt volna erre nem jutot volna. (PéldK. [1510] 28)

'The soldier said. Judge, sir, please tell everyone to keep quiet. When this happened, the soldier said. Why, judge, this is the first true statement here. [...] Having heard all this, the judge said to the people standing by. Is it true what this soldier says? To which they said. Had he not been a wrong-doer, he would not have come to this.'

In (6), the referential centre is shifted to a new discourse participant with each turn: first to the soldier, then to the judge, and finally to the people standing by. In the last turn, for instance, the past conditional verb forms volt volna '(lit.) would have been' and jutott volna 'would have got/come (somewhere)' evoke a hypothetical reality prior to the time of the discourse, and they both receive their interpretation with respect to the referential centre of the embedded (group of) speakers. By contrast, the quoting clauses have their verb forms in the narrative past; hence, the complete displacement of the referential centre in the embedded utterance cluster (see Verschueren 1999, 131-4) is marked by a corresponding shift in tenses.

3.2. As opposed to direct speech, indirect speech only requires the actual speaker to focus on the propositional content of the embedded utterance or utterance part, without regard to its original form. As a result, the referential centre is not displaced onto the embedded speaker; rather, it continues to reside with the actual speaker. With the grammaticization of dependent clause constructions, it has become increasingly possible for the actual speaker to extend her perspective beyond the quoting clause onto the embedded utterance.

(7) (a) A látogatás után pedig éppen ő kezdett faggatni, hogy mért mentünk oda. (Mészöly 1979, 19)

'After the visit he himself started grilling me why we had gone there.'

(b) Teleszkai gondosan bezárta az ajtót, az ablaktáblát is behajtotta; s csak akkor kérdezte meg, hogy vigyen-e haza [...], vagy gyalog akarok hazamenni. (Mészöly 1979, 26)

'Teleszkai locked the door carefully, then he closed the window-pane as well, and it wasn't until then that he asked me whether he should take me home or I preferred walking.' 
(c) Fennhangon magyarázta, hogy mi lesz a teendő, a szekeret hogyan készítjük elő, s a fenékdeszkák alá, a zsámolyokra hogyan csúsztatunk gumi alátétet. (Mészöly 1979, 7)

'He explained vehemently what the task was going to be, how we would prepare the wagon, and slide rubber pads under the floor-boards, on the stools.'

In (7a), Teleszkai's question is quoted in indirect speech. The original question may have taken the following form (although other options are also conceivable): Mondd, miért is jöttünk ide? 'Tell me, why have we come here?' As shown by the spatial deictic expressions mentünk 'we went' and oda 'there', the centre of orientation is determined by the actual rather than the embedded speaker's position in space. Note that there is also a difference between the actual utterance and the embedded one in terms of their positions in time. However, this is not explicitly marked by (7a), since Modern Hungarian has only a single past tense paradigm, which results in the neutralization of formal distinctions for expressing temporal antecedence vis-à-vis the speech event and the reference event.

Although the centre of interpersonal orientation resides with the actual speaker rather than the embedded one, the verb form mentünk 'we went' in the indirect quote and the reconstructed form jöttünk 'we have come' are both in first person plural. However, this is clearly no more than a formal coincidence. In the reconstructed version, the first person plural form is used inclusively to refer to the interlocutors of the discourse being evoked. By contrast, the corresponding verb form in the indirect quote refers to two participants in the story, without including the addressee of the actual speaker's utterance; hence, this amounts to an exclusive use of first person plural.

Unlike (7a), (7b) has a way of unambiguously marking that the centre of interpersonal orientation is the actual speaker. Here, the embedded speaker is evoked by a third person verb form (vigyen-e "whether he should take me'), whereas the embedded addressee is associated with first person singular (akarok 'I want'), suggesting that the latter may be identified as the reported ego of the actual speaker.

The use of indirect speech does not necessarily entail that the actual speaker needs to provide an accurate and complete rendition of the propositional content of the embedded utterance (cf. Short 1994, 1838). Rather, there are cases where the actual speaker is intent only on supplying a summary of what the relevant discourse (part) is about. One possible reason behind this is that indirect speech is expressed by a highly 
grammaticized construction whose use is generally limited to a single clause or two at a time. In (7c), which provides a summary of the plans of a discourse participant, the events are represented from the actual speaker's perspective, hence the functioning of the referential centre is similar to what (7a-b) illustrate.

In early Hungarian literary tradition, the displacement of the referential centre had more varied forms of expression, as a result of a richer system of tense and mood paradigms evolving under the influence of Latin (cf. section 3.1). Although this system was not sufficiently well established to facilitate the unequivocal marking of the centre of temporal orientation, Old Hungarian texts nevertheless show a more rigorous way of establishing the referential centre of the actual speaker.

(8) az harmad foror keri vala ez ezweget hogi halala vttan — meg terne. (PéldK. [1510] 2-3)

'The third nun asked the widow that she convert after her death.'

In (8), the use of the conditional verb form megtérne ('convert-cond-3sg') in the subordinate clause is motivated by the fact that the referential centre resides with the actual speaker. Since in the quoting (main) clause the verb is inflected for past tense, the sequence of tenses dictates (under the influence of Latin) the choice of this particular verb form in the embedded clause. In Latin, the verbal paradigms expressing conditional and subjunctive are formally identical. Hence, in an effort to imitate the original, the author of the Hungarian text extends the use of the corresponding Hungarian conditional form to subjunctive contexts (cf. Haader $2003,517)$. In terms of interpersonal orientation, the actual speaker retains her dominant position in the embedded clause, as is unambiguously marked by the third person singular forms associated with the embedded addressee.

Just like direct speech, indirect speech also allows for the quoting of conversations with multiple speakers. The crucial difference is that here the actual speaker limits her attention to the propositional content of the embedded utterance, which allows her to retain control of the referential centre.

(9) es megkerde ewtett ha valamyt vallottuolna vr yftentewl \% ky felele hogÿ femmÿt nem valottuolna (JókK. [1372 u./1448k.] 134)

'and he asked him if he had spoken about the Lord, to which he replied he had not spoken about him' 
As the pronouns and verbs in (9) suggest, the centre of interpersonal orientation is the actual speaker here. The third person singular personal pronoun ottet 'him/her' refers to the addressee of the first turn in the conversation; accordingly, the clause representing this turn also has its past conditional verb form zero-inflected for third person singular (vallott volna 'would have spoken/confessed'). The same applies to the turn in reply: the quoting clause evokes the speaker of the second turn with a third person singular verb form (felele 'replied-3sg'), and the verb inflected for a coreferential subject is also in a similar form in the subordinate clause. In terms of temporal orientation, the perspective of the quoting person extends to the full length of the embedded utterance. As we have noted above, Old Hungarian had a way of making this especially conspicuous by adopting a wide range of tenses (at least in the written register). The system is also evident in the example at hand, with narrative past used in the quoting clause, and past conditional in the embedded one.

At a general level, the functioning of the referential centre in Hungarian indirect speech is different from the situation in, e.g., English, German, French, or Latin in that the grammatical features of tense and mood which could be used to distinguish the actual speaker's vantage point from that of the embedded speaker either have not developed or have not gained currrency. Although adverbs, pronouns, and elaborate nominal expressions functioning as adverbials provide a way of distinguishing between the two vantage points (cf. most 'now' vs. akkor 'then', ma 'today' vs. aznap 'that day', tegnap 'yesterday' vs. a megelözö nap 'the day before', jövöre 'next year' vs. a következö évben 'the following year', etc.), the tense and mood paradigms of Hungarian verbs cannot be used to similar effect. One likely reason behind this is that (unlike the prototypical time deictic expressions just listed) tenses also have a use whereby their interpretation is not bound to the context-dependent vantage point(s) of the actual speaker in the speech event (cf. Langacker $2002,8-11) .{ }^{11}$ In the final analysis, it seems fair to say that indirect speech cannot be applied with such formal rigour to the marking of temporal orientation in Hungarian as in the other languages mentioned above.

${ }^{11}$ Past tense verb forms used without a context-dependent point of reference are commonly found in fiction, i.e., in cases where there is no referential connection between the speech event and the reference event. In such situations, past tense may simply have a distancing function (as illustrated by the phrase once upon a time at the beginning of tales): they locate the events at an indeterminate point in time (cf. Tátrai 2002, 85-92; 2008). 
3.3. In addition to the options discussed with respect to direct and indirect speech, the actual speaker may also represent the embedded discourse or discourse part by displacing the referential centre only partially. This mode of quoting is thus characterized by the joint functioning of multiple referential centres. In other words, we are faced with an intermediate case here, situated between direct speech (with a complete displacement of the referential centre) and indirect speech (with the actual speaker retaining her referential centre), which can be described as a typical realization of free indirect speech (cf. Kocsány 1996, 337; Tátrai 2005, 223).

(10) (a) Teleszkait meglepte, hogy ennyire kihalt minden. (Mészöly 1979, 22)

'Teleszkai was surprised that everything was [literally 'is', signalled by a zero copula in 3sg indicatives] ${ }^{12}$ deserted like this.'

(b) Amikor visszaültem melléje, azt mondta, elfelejtette bezárni a présházajtót, most már jobb is, hogy így történt. (Mészöly 1979, 18)

'When I sat down next to him, he said he had forgotten [lit. 'forgot'] to lock the door of the wine-press house, now it's better anyway for it to have happened so.'

In (10a-b), the actual speaker adopts a construction typically associated with indirect speech. However, while indirect speech has the quoted part represented from the actual speaker's vantage point (apart from the problems concerning the disambiguation of perspectives in temporal orientation, cf. 3.2), (10a-b) feature a partial displacement of the referential centre onto the embedded speaker. In (10a), the proximal demonstrative pronoun ennyire 'to this degree, like this' reflects the adoption of the embedded discourse participant's vantage point (from which he observes the immediate surroundings) rather than that of the actual speaker. This

12 These passages are difficult to translate because of wide-ranging differences between English and Hungarian embedding. As opposed to languages like English, Hungarian has no 'sequence of tenses' (or a less rigorous application of the actual speaker's perspective): contemporaneity with the main clause is expressed by the present tense of the embedded clause's verb. As a result, it is often difficult to distinguish between cases of indirect speech and free indirect speech: tense itself fails to disambiguate the two possible vantage points. Further complications are caused by the fact that Hungarian tends to move toward the type of system attested in English: the past tense of the embedded verb may increasingly signal contemporaneity (when the clause is represented from the actual speaker's perspective), although originally this pattern was mainly reserved for cases of plusquamperfect. To handle these problems, we provide a literal translation in each case. 
is further reinforced by the present-tense form of the verbal predicate in the subordinate clause, which again confirms the status of the embedded speaker as the centre of temporal orientation. Were the actual speaker to maintain his own vantage point, the sentence would probably take the following form (although see footnote 12): Teleszkait meglepte, hogy annyira kihalt volt minden 'Teleszkai was surprised that everything was [lit. 'was'] deserted like that'. In (10b), the actual speaker's referential centre continues to operate in the subordinate clause (following the quoting clause azt mondta 'he said') as there are no traces of any displacement of the centres of interpersonal and temporal orientation. In the second part of the quotation, however, the centre of temporal orientation does shift onto the embedded speaker, as the use of most 'now' suggests. ${ }^{13}$

Generally speaking, it seems that there are multiple options for partially displacing the referential centre. On the one hand, this may occur within a single clause: for example, when the actual speaker retains the centre of interpersonal orientation, while temporal orientation is determined by the embedded one. On the other hand, the centre of referential orientation may also be shifted as we move from one clause to another.

Free indirect speech results from the fact that the actual speaker is either unwilling or unable to provide a complete direct or indirect rendition of the embedded utterance by maintaining its organization of perspective. From a historical perspective, it may be worth noting that (especially in oral texts, i.e., in documents reflecting the oral register) the partial displacement or free movement of the referential centre is attested as early as the Old Hungarian period. The quotation is introduced by a quoting clause, and the referential centre is fully or partially displaced onto the embedded speaker. A closely related phenomenon is that (particularly in the codices) the scriptor manifests an intention to produce grammatical forms that most directly evoke the corresponding Latin devices. In several cases, he cannot live up to this standard, or at least not for the full length of the quotation. Hence, it seems plausible to suggest that some instances of free indirect speech in Old Hungarian result from an inconsistent use of Latinate forms (in turn caused by the wide-ranging grammatical differences between the two languages).

13 The use of the discourse deictic expression igy 'like this' is indifferent here, as it may refer back to an event in the immediate past from either the actual or the embedded speaker's perspective. 
(11) (a) Ge mundoa neki meret nū eneýc. ẏfa ki nopun emdul oз gimilftwl. halalnec halalaal hols. (HB. [1192-95])

'But he told him why he should not eat: on the day you eat from that fruit, you shall die a horrible death.'

(b) Barbel Janos hiti szerient azt mondgia, hogi masod kapalaskor, mikor az nagi szeoleot kapalta, tistarto vram akor ment en hoszam, (Úriszék [18 July 1613] 274)

'János Barbel says in good faith that during the second hoeing, when he was hoeing in the great vineyard, that's when the lord of the manor came to me'

As (11a) illustrates, the earliest surviving Hungarian text (Halotti Beszéd és Könyörgés [HB.]/Funeral Speech and Prayer, cca. 1192-95) already adopts a mode of quoting which can be interpreted as an instance of free indirect speech. Note that in the subordinate clause of the first sentence, the centre of interpersonal orientation is not displaced onto the embedded speaker; rather, the propositional content of the utterance is simply summarized from the actual speaker's perspective. In the subsequent passage, however, the embedded addressee (introduced into the discourse world by the personal pronoun neki 'to him' in the first sentence) is represented from the embedded speaker's vantage point, as suggested by the second person singular verb form halsz 'you die'.

In (11b), the panel azt mondja, hogy 'he says that ...' (characteristic of indirect speech) is followed by an adverbial clause (másod kapáláskor, mikor az nagy szőlöt kapálta 'during the second hoeing, when he was hoeing in the great vineyard') in which the referential centre resides with the actual speaker. By contrast, the next passage represents the basic event ( $a$ tiszttartó uram akkor ment énhozzám 'that is when the lord of the manor went up to me') from the embedded speaker's perspective. It is only in relation to this position that the self-referential expression énhozzám 'to me' (pointing to himself in the past) and the honorific address tiszttartó uram (lit. 'my [good] sir the manor lord') receive their interpretation. At the same time, the centre of spatial orientation is retained by the actual speaker, as suggested by the use of ment 'he went' instead of jött 'he came', which would have reflected the embedded speaker's perspective. Finally, it deserves special mention that, unlike some previous passages we have seen, (11b) is not a piece of translation. Hence, part of the reason why the referential centre may be on the move is that the author is free from the limitations of having to reflect the tense and mood relations of the Latin text in Hungarian. 
From our broad definition of free indirect speech as a heterogeneous category it follows that the category also includes cases of 'adjoined direct speech' (cf., e.g., Haader 2003), since the latter also show an intermingling of properties of both direct and indirect speech.

(12) [...] Blaskouich vram mond Baraszouith Martonnak: hogj io Marton vram, az en fl. 80 adossagomnak az napiaÿs ma wagion, hogi le teszed. (Úriszék [18 July 1613] 274)

'Mr Blaskovich told Marton Baraszovith that good Sir Marton, today is the day when you are due to pay back my loan of fl. 80 .'

In (12), the embedded utterance is introduced by the subordinating conjunction (or complementizer) hogy 'that', which explicitly marks the grammatical relation between the two clauses in a way characteristic of indirect speech. However, the subsequent quote is formulated in the conventions of direct speech, with a complete displacement of the referential centre. From a pragmatic perspective, there seems to be no sound reason for making a sharp distinction between these cases and the ones in $(10 \mathrm{a}-\mathrm{b}, 11 \mathrm{a}-\mathrm{b})$ above, which also mark a shift of the referential centre from the actual speaker onto the embedded one.

The actual speaker can also adopt free indirect speech (with the partial displacement of the referential centre) for embedding conversations, as an increasing number of examples show from the second half of the 19 th century.

(13) Arról beszéltek egymás közt, hogy mármost mit csináljanak ezzel a nyakukra hozott leánnyal. (Jókai 1873/1981, 133)

'They were discussing between themselves what they should do now with this nuisance of a girl.'

(13) provides a summary of the embedded discourse participants' conversation. However, although the centre of interpersonal orientation resides with the actual speaker, the passage departs from prototypical cases of indirect speech by the employment of the deictic expressions mármost 'now' and ezzel a lánnyal 'with this girl' reflecting the embedded speakers' perspective. 


\section{Quoting and (meta)pragmatic awareness}

We hope to have shown in the previous section that the study of perspective (concerned with the functioning of the referential centre) may serve as an adequate basis for the pragmatic analysis of various modes of quoting. However, in the kind of functional cognitive framework we endorse, such an analysis also needs to address the question of what levels of awareness (cf. Verschueren 1999, 173-200) are associated with the mental processes inherent in the act of quoting, and how this may affect the organization of perspective. In this context, the two contextdependent vantage points seem to require slightly different approaches. On the one hand, the displacement of the subject of consciousness seems to call for an analysis of the metapragmatic reflection manifested in the matrix utterance. On the other, the functioning of the referential centre may be better understood by analysing the level of pragmatic reflection associated with the embedded part.

The notion of metapragmatic awareness covers all aspects of reflecting on language use as meaningful functioning (Verschueren 1999, 187-98), ${ }^{14}$ which provides the domain in which quoting is interpreted here. Crucially, not only can speakers reflect on their own speech production or its reception by a partner, but also on the linguistic activity of those whose utterances they choose to embed (partly or fully) into their own. From our perspective, the study of metapragmatic reflection is made relevant by the fact that the extent to which perspectivity is linguistically marked (by the displacement of the subject of consciousness) strongly correlates with the level of metapragmatic reflection involved. This is because the linguistic signals of embedding serve the metapragmatic purpose of contextualizing the appropriate utterances as quotations (cf. Verschueren 1999, 194-5; Tátrai 2004, 58-60). Hence, the more elaborately the context of embedding is signalled by the quoting part (in other words, the more thematization the contextualizing process receives), the higher the level of metapragmatic reflection manifested in the act of quoting.

A further important concern is to address the question of how much (and in what way) the quoted discourse is separated from the surrounding text. In opposition to indirect speech (with the speaker focussing only on the propositional content of the embedded utterance), direct speech is supposed to render the form as well as the content of the utterance be-

${ }^{14}$ For a different, slightly broader interpretation of metapragmatics, see Mey (2001, 173-205). 
ing evoked, which may be expressed in writing by various metapragmatic signals. Devices such as the use of quotation marks, italics, or dashes (with or without a quoting clause) have become standard orthographic conventions for marking direct speech. At the other extreme, cases of free indirect speech lacking both quoting clauses and other types of metapragmatic signals show a very low level of metapragmatic reflection (for a more detailed discussion, see Csontos-Tátrai 2008, 95-105).

The notion of pragmatic awareness concerns the operation of mental processes related to the production and reception of utterances. The key observation is that discourses may differ in terms of the level of reflection involved in their processing (the dynamic meaning generation in the context of adaptation). In some cases, the discourse participants select and employ the appropriate linguistic devices almost automatically, with minimal effort; while in other cases the same processes may require substantial mental work (cf. Verschueren 1999, 173-87). Of course, the relevant questions may also be posed in relation to quoting, as the representation of quoted utterances may show varying degrees of reflection in terms of the mental processes of planning and memory retrieval. It seems plausible to suggest that the typical quoting modes discussed above show characteristic differences in this respect, in close correlation with the functioning of the referential centre. In particular, direct speech (with the complete displacement of the referential centre onto the embedded speaker) and indirect speech (with the retention of the referential centre with the actual speaker) may be described as showing higher levels of pragmatic reflection (albeit for different reasons) than the instances of free indirect speech featuring a partial displacement of the centre of spatio-temporal and interpersonal orientation.

Direct speech is usually associated with a higher level of pragmatic reflection because the actual speaker is intent on providing a literal rendition of the embedded speaker's utterance, attending to its form as well as its propositional content. This means that the actual speaker needs to be consistent in adopting and maintaining a centre of interpersonal and spatio-temporal orientation different from her own. When there is a direct referential connection between the actual speaker and the embedded one; in other words, when there is a spatio-temporal continuity between the two speech events (cf. Tátrai 2005; 2008), the actual speaker needs to give an accurate (and therefore highly reflected) reconstruction of the utterance in question. In cases of hypothetical quotation, the actual speaker needs to construe authentically what could have been said 
in the past, or could be said in the present or future. All this requires conscious planning. A similar reasoning applies to situations showing a complete lack of referential connection between the two speech events. In such cases, the actual speaker needs to imagine in detail, and construe with conscious planning, what the fictitious character she has invented might say in the relevant context.

It is for a different reason that indirect speech also shows a relatively high level of pragmatic reflection. Here, this results from the fact that the actual speaker only focuses on the propositional content of the utterance and adopts a highly grammaticized construction for representing it. On the one hand, this prompts her to ignore signals pertaining to the embedded speaker's register and speaker attitude, with all such information transferred to the quoting part for the purposes of metapragmatic reflection. On the other hand, the actual speaker also needs to apply consistently all the referential shifts that allow her to evoke the embedded discourse from her own vantage point rather than the original one.

By contrast, the cases of free indirect speech that show a partial displacement of the referential centre seem to reflect lower levels of pragmatic reflection with their more liberal use of grammatical devices. When the actual speaker is referentially linked to the world of the embedded discourse, her recalling of the utterance is determined by the functioning of long-term memory. This facilitates the joint implementation of multiple vantage points (referential centres), as long-term memory prioritizes content with occasional spells of literal renditions. At the same time, this looser mode of quoting requires lower levels of conscious planning, whether or not there is a referential connection between the actual speaker and the embedded one. This is because in such cases the actual speaker need not rely consistently on either her own referential centre or that of the embedded speaker, which consequently demands less mental effort. Hence, it may be speculated that the most basic and natural mode of quoting (the one associated with the lowest level of pragmatic reflection) is the type of free indirect speech characterized by the partial displacement of the referential centre. This may be part of the reason why Hungarian has not developed tense and mood inflections for distinguishing the centres of orientation associated with the actual speaker and the embedded one in cases of indirect speech.

This preliminary discussion of the levels of pragmatic awareness involved in each mode of quoting further highlights the need for applying the concepts of textual typology in pragmatic research. In particular, 
it cannot be a coincidence that the literary discourses inherently showing the highest levels of pragmatic reflection (and demanding substantial mental work) have a marked preference for the more fixed modes of quotation, i.e., either direct or indirect speech as a function of the actual speaker's quoting strategy. Free indirect speech, by contrast, is more frequent in genres bearing a stronger relation to the oral register and showing a lower level of pragmatic reflection (e.g., manor court minutes, autobiographies). Naturally, this does not preclude the possibility that free indirect speech may also become a consciously employed stylistic device (figure of speech), as indeed it did in late 19th, early 20th century Hungarian fiction, a few centuries after direct speech had acquired a similar role.

\section{Summary}

In this paper, quoting has been interpreted as a prototypical realization of perspectivity in language. Whenever the actual speaker evokes someone else's discourse, and displaces the subject of consciousness onto another person, her act of quoting (no matter what form the quotation takes) inherently involves perspectivization. Accordingly, modes of quoting can be characterized by examining how, and to what extent, the displacement of speaking as a sign of active consciousness is explicitly marked. However, the notion of perspectivization has also been extended in such a way as to include the issues of referential interpretation and grounding as well.

As regards the functioning of the referential centre, the three main modes of quoting may be described as follows.

- In direct speech, the referential centre (for spatio-temporal and interpersonal orientation) is completely displaced onto the embedded speaker.

- In indirect speech, the actual speaker and her position in space and time represent the centre of referential orientation.

- In (some cases of) free indirect speech, the referential centre is partially shifted onto the embedded speaker. In other words, the actual speaker and the embedded one make a joint contribution to the organization of perspective in the embedded utterance.

Throughout the paper, we have been concerned not only with the universal pragmatic aspects of quotation but also with the language-specific 
features of Hungarian, including the historical development of its quoting strategies. No attempt has been made to provide a systematic full-scale presentation of the evolution of various modes of quotation; rather, historical facts have only served the purpose of illustrating the applicability of a general interpretive framework (for more detail, see Csontos-Tátrai 2008). Still, the following Hungarian-specific generalizations seem to receive sufficient empirical support.

- Compared to present-day Hungarian, the language of early Hungarian literary tradition was better suited to mark subtle differences of perspective with its wider range and more specialized use of tense and mood inflections. However, even this system was less than fully consistent in distinguishing between the actual speaker's vantage point and that of the embedded one in all tenses and moods.

- In cases of direct speech, the presence of a quoting clause (marking perspectivization) was generally expected up until the mid-19th century. By that time, orthographic conventions (italics, quotation marks, and dashes) had gradually acquired the role of signalling direct speech by themselves.

- Indirect speech results from the grammatical integration of two independent clauses; hence, the presence of a quoting clause has been a precondition for the appearance of indirect speech since the earliest surviving records of Hungarian.

- Another important feature of indirect speech (again already attested in Old Hungarian) is its tendency to operate with a wider variety of quoting verbs than direct speech. This variety may be explained by the fact that in indirect speech, the quotation itself is only supposed to render the propositional content of the embedded utterance, which means that any possible indications of speaker attitude are left for the quoting part to express.

- Examples of the kind of free indirect speech characterized by the partial displacement of the referential centre come predominantly from corpus segments bearing a stronger relation to the oral register and/or showing a lower level of pragmatic awareness.

- In early texts, it is not uncommon for the first part of the passage to apply the conventions of indirect speech, only to be followed by a quote with a partial or complete displacement of the referential centre. 
- A further important trend is that wherever possible, the scriptors of codices attempt to provide Hungarian grammatical forms that unmistakably evoke the corresponding forms in Latin. This ideal, however, proves impossible to achieve in many cases, as a result of wide-ranging differences between the two languages.

- Finally, the second half of the 19th century saw the emergence of free indirect speech as a consciously employed stylistic device (narrative technique). In this context, free indirect speech helps exploit the possibility of creating ambiguity by blurring the boundaries of perspectivization.

\section{Sources}

Báróczy 1814 = Báróczynak Minden Munkáji. Újra kiadta Kazinczy Ferenc. Nyolczadik kötet. Trattner János Tamás, Pest. 1814.

HB. = Halotti Beszéd 1192-95. In: Benkő Loránd 1980. Az Árpád-kor magyar nyelvü szövegemlékei. Akadémiai Kiadó, Budapest.

JókK. = Jókai-kódex 1372 u./1448 k. A nyelvemlék betűhű olvasata és latin megfelelője. Codices Hungarici VIII. Bevezetéssel és jegyzetekkel ellátva közzéteszi: P. Balázs János. Akadémiai Kiadó, Budapest. 1981.

Jókai Mór 1873/1981. Az arany ember. Szépirodalmi Könyvkiadó, Budapest.

Mészöly Miklós 1979. Szárnyas lovak. Szépirodalmi Könyvkiadó, Budapest.

PéldK. = Példák Könyve 1510. Codices Hungarici IV. Jegyzetekkel és tanulmánnyal kísérve közzéteszi: Bognár András és Levárdy Ferenc. Akadémiai Kiadó, Budapest. 1960.

Úriszék = Úriszék 16-1\%. századi perszövegek. Magyar Országos Levéltár Kiadványai II. Akadémiai Kiadó, Budapest. 1958.

[Vég-Veresmarti Sámuel] 1797. Drága Talentomnak, akarat ellen való el-ásása. Trattner Mihály, Pest.

WinklK. = Winkler-kódex 1506. Codices Hungarici IX. Bevezetéssel és jegyzetekkel ellátva közzéteszi: Pusztai István. Akadémiai Kiadó, Budapest. 1988.

\section{References}

Abaffy, Erzsébet E. 1991. Az igemód- és igeidő-rendszer [The system of mood and tense]. In: Loránd Benkő - Erzsébet E. Abaffy - Endre Rácz (eds): A magyar nyelv történeti nyelvtana. 1. kötet: A korai ómagyar kor és előzményei [A historical grammar of Hungarian. Volume 1: Early Old Hungarian and its antecedents], 104-121. Akadémiai Kiadó, Budapest.

Beaugrande, Robert-Alain de-Wolfgang U. Dressler 1981. Introduction to text linguistics. Longman, London \& New York.

Acta Linguistica Hungarica 56, 2009 
Blank, Andreas-Peter Koch (eds) 1999. Historical semantics and cognition. Mouton de Gruyter, Berlin \& New York.

Bruner, Jerome 1986. Actual minds, possible words. Harvard University Press, Cambridge MA.

Bühler, Karl 1934. Sprachtheorie. Die Darstellungsfunktion der Sprache. Fischer, Jena.

Cohn, Dorrit 1978. Transparent minds. Narrative modes for presenting conciousness in fiction. Princeton University Press, Princeton NJ.

Csontos, Nóra 2009. A hermeneutical approach to graphemes. In: Annales Universitatis Scientiarum Budapestinensis. Sectio Linguistica.

Csontos, Nóra-Szilárd Tátrai 2008. Az idézés pragmatikai megközelítése (Az idézési módok vizsgálatának lehetőségei a magyar nyelvű írásbeliségben). [A pragmatic approach to quoting. (Modes of qouting in written Hungarian)]. In: Általános Nyelvészeti Tanulmányok $22: 59-121$.

Evans, Vyvyan 2007. A glossary of cognitive linguistics. The University of Utah Press, Salt Lake City.

Fillmore, Charles 1975. Santa Cruz lectures on deixis. Indiana University Linguistics Club, Bloomington.

Genette, Gerard 1997. Palimpsests. University of Nebreska Press, Lincoln \& London.

Givón, Talmy 1990. Syntax: A functional-typological introduction. Vol. 2. John Benjamins, Amsterdam \& Philadelphia.

Givón, Talmy 1998. The functional approach to grammar. In: Michael Tomasello (ed.): The new psychology of language. Cognitive and functional approaches to language structure, 41-65. Lawrence Erlbaum Associates, Mahwah NJ.

Haader, Lea 2003. Az összetett mondat. Az alárendelö mondat [The complex sentence. The subordinate clause]. In: Kiss-Pusztai (2003, 500-51).

Kiss, Jenő-Ferenc Pusztai (eds) 2003. Magyar nyelvtörténet [The history of Hungarian]. Osiris Kiadó, Budapest.

Kocsány, Piroska 1996. A szabad függő beszédtől a belső monológig [From free indirect speech to the stream of consciousness]. In: István Szathmári (ed.): Hol tart ma a stilisztika? Síluselméleti tanulmányok [Studies in the theory of style], 329-48. Nemzeti Tankönyvkiadó, Budapest.

Langacker, Ronald W. 1987. Foundations of cognitive grammar, Vol. 1: Theoretical prerequisites. Stanford University Press, Stanford.

Langacker, Ronald W. 2001. Topic, subject, and possessor. In: Hanne Gram SimonsenRolf Theil Endresen (eds): A cognitive approach to the verb. Morphological and constructional perspectives, 11-48. Mouton de Gruyter, Berlin \& New York.

Langacker, Ronald W. 2002. Deixis and subjectivity. In: Frank Brisard (ed.): Grounding. The epistemic footing of deixis and reference, 1-28. Mouton de Gruyter, Berlin \& New York.

Levinson, Stephen C. 1983/1992. Pragmatics. Cambridge University Press, Cambridge.

Levinson, Stephen C. 2004. Deixis. In: Laurence R. Horn-Gregory Ward (eds): The handbook of pragmatics, 97-121. Blackwell, Oxford \& Malden MA.

Lyons, John 1977/1989. Semantics. Vol. 2. Cambridge University Press, Cambridge. 
Mey, Jacob 2001. Pragmatics: An introduction. Second edition. Blackwell, Oxford \& Malden MA.

Murvai, Olga 1980. Szöveg és jelentés. A szabad függő beszéd szövegnyelvészeti megközelítése [Text and meaning. The text linguistics of free indirect speech]. Kriterion, Bukarest.

Sanders, José-Wilbert Spooren 1997. Perspective, subjectivity, and modality from a cognitive linguistic point of view. In: Wolf-Andreas Liebert-Gisela RedekerLinda Waugh (eds): Discourse and perspective in cognitive linguistics, 85-112. John Benjamins, Amsterdam \& Philadelphia.

Sárosi, Zsófia 2003. Az ómagyar kor. Morfématörténet [The Old Hungarian period. Morphological changes]. In: Kiss - Pusztai (2003, 352-71).

Short, Michael 1994. Understanding texts: Point of view. In: Gillian Brown-Kirsten Malmkjaer - Alastair Pollitt - John Williams (eds): Language and understanding, 170-90. Oxford University Press, Oxford.

Sinha, Chris 1999. Grounding, mapping and acts of meaning. In: Theodorus A. Janssen-Gisela Redeker (eds): Cognitive lingusitics: Foundations, scope, and methodology, 223-55. Mouton de Gruyter, Berlin \& New York.

Sinha, Chris 2001. The epigenesis of symbolization. Manuscript. (http://www.lucs.lu.se/ftp/pub/LUCS_Studies/LUCS85/Sinha.pdf)

Tátrai, Szilárd 2002. Az 'ÉN' az elbeszélésben. A perszonális narráció szövegtani megközelítése [The 'I' in narratives. The text linguistics of personal narration]. Argumentum Kiadó, Budapest.

Tátrai, Szilárd 2004. A kontextus fogalmáról [On the notion of context]. In: Magyar Nyelvőr 128: 479-94.

Tátrai, Szilárd 2005. A nézőpont szerepe a narratív megértésben [The role of perspective in narrative understanding]. In: Általános Nyelvészeti Tanulmányok 21 : 207-29.

Tátrai, Szilárd 2008. Perspective and deixis in narrative discourses. In: Gábor Tolcsvai Nagy (ed.): Function and genres (Metalinguistica 20), 257-70. Peter Lang, Frankfurt am Main.

Tolcsvai Nagy, Gábor 2001. A magyar nyelv szövegtana [The text linguistics of Hungarian]. Nemzeti Tankönyvkiadó, Budapest.

Tomasello, Michael 1999. The cultural origins of human cognition. Harvard University Press, Cambridge MA.

Verschueren, Jef 1999. Understanding pragmatics. Arnold, London.

Zlatev, Jordan 1997. Situated embodiment: Studies in spatial semantics. Gotab, Stockholm. 